\title{
Exploring the contribution of housing adaptations in supporting everyday life for people with dementia: a scoping review
}

\author{
Rita Newton ${ }^{1 \star(D), ~ S u e ~ A d a m s ², ~ J o h n ~ K e a d y ~}{ }^{1,3}$ (D) and Emmanuel Tsekleves ${ }^{4}$ \\ ${ }^{1}$ Division of Nursing, Midwifery \& Social Work, The University of Manchester, Manchester, UK, ${ }^{2}$ Care \& \\ Repair England, The Renewal Trust Business Centre, Nottingham, UK, ${ }^{3}$ Greater Manchester Mental Health \\ NHS Foundation Trust, Prestwich, Manchester, UK and ${ }^{4}$ ImaginationLancaster, Lancaster Institute for \\ Contemporary Arts, Lancaster University, Lancaster, UK \\ ${ }^{\star}$ Corresponding author. Email: rita.newton@manchester.ac.uk
}

(Accepted 2 September 2021)

\begin{abstract}
The primary aim of this scoping review was to explore the contribution of housing adaptations to supporting everyday life for people with dementia living at home in the community. The study adopted a scoping review methodology which was guided by the Joanna Briggs Institute Reviewers Manual. Four review questions were developed which subsequently informed the inclusion criteria and search terms. Eight databases were searched resulting in 2,339 records, with 13 papers being included in the review. Evidence from the review found that the most common adaptations were recommended and/or implemented to compensate for a person's physical limitations and for safety reasons, rather than adaptations to support activities of daily living for a person with dementia. Support to implement adaptations was provided by a range of professionals coupled with 'trial and error' approaches adopted by the person themselves, and these were seen as key enablers. Barriers to implementing and using adaptations were fourfold: (a) access to information, (b) knowing when to make changes, (c) carer resistance, and (d) the unsuitability of the home. It would appear that housing adaptations have a positive impact on both the person with dementia and the carer (where one is present), with some adaptations having a relatively sustained impact and being particularly effective if implemented early in the lived trajectory of dementia.
\end{abstract}

Keywords: dementia; housing adaptation; housing modification; living in the community; scoping review

\section{Introduction}

Within the United Kingdom (UK), the majority (61\%) of older people with dementia live in their own home, in the community (Wittenberg et al., 2019), with most spending around 90 per cent of their time indoors, predominantly within the home (Deguen and Zmirou-Navier, 2010). Consequently, the everyday surroundings and 
place where people live impacts on health and subjective wellbeing (Braubach, 2011). In turn, this affects personal independence, functionality, social activity and quality of life (World Health Organization, 2011). For people with dementia, the home environment is of particular importance, both as a place of memories (Chaudhury, 2008) and as a physical entity (Soilemezi et al., 2017a). Improving housing conditions to maximise safe, independent living and enhance quality of life is therefore essential (National Disability Authority, 2015).

Whilst there has been very little research on adapting and future-proofing homes to support ageing in place (Torrington, 2014), being supported to live well with dementia at home and in the community has increasingly become a policy and practice imperative in the UK (Department of Health, 2012, 2015; National Institute for Health and Social Care Excellence, 2018; All-Party Parliamentary Group on Dementia, 2019).

Undertaking appropriate adaptations to the home environment at the right time and in the right way can enhance quality of life for people with dementia and their carers. As stated by Heywood, a housing adaptation should be like

a transformation in which the barriers that have turned someone's home into a place of embarrassment and confinement are removed, and their home is restored to them. (Heywood, 2005: 531)

Home adaptation design guidelines exist to assist people with dementia, families and professional agencies to consider how to adapt/modify a home in order to minimise such encountered barriers and render it more 'dementia friendly' (see e.g. Alzheimer's Society, 2015; Hammond Care, 2015; Alzheimer's Australia, 2017; Care and Repair England with Silverlinks, 2017; Dementia Services Development Centre, 2017). However, current design guidelines for the adaptation of the everyday home environment have been shown through systematic reviews to lack a rigorous empirical evidence base (Marquardt et al., 2014; Struckmeyer and Pickens, 2016).

To try to bridge this gap in understanding, and better evidence the design guidelines field, the overarching aim of this scoping review is to explore the contribution of housing adaptations in supporting the everyday life of people with dementia. This aim informed the development of a set of four review questions for further investigation, namely:

(1) Which housing adaptations are being implemented and used by people with dementia and their carers on an everyday basis?

(2) How are decisions made to implement and use housing adaptations, or otherwise?

(3) What are the barriers and enablers to housing adaptation implementation and use?

(4) What is the impact of the housing adaptation on everyday life?

The aim was kept deliberately broad as this is consistent with scoping review methodology (Tricco et al., 2018b) since it sought to ask what is the nature of evidence for this intervention (housing adaptations) and what is known about this concept. 
Mainstream housing

Individual homes to buy or rent - not designated for any specific user group though Lifetime homes includes age-friendly features and Wheelchair homes are specifically designed. Personal care, support, other services and amenities available within the community.

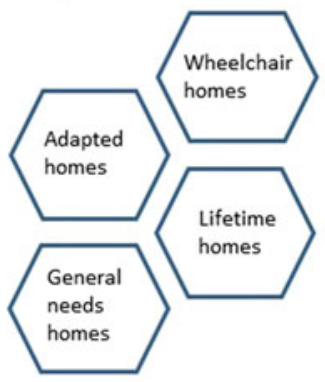

Specialised housing

Groups of homes (usually flats) to buy or rent designated for older people (typically 55+). Personal care and support usually arranged or provided within the development together with shared facilities and activities.

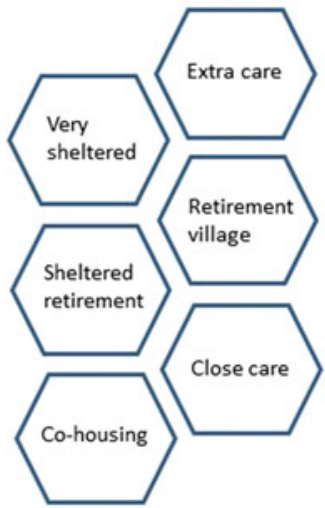

Figure 1. Spectrum of housing options as defined by Housing Our Ageing Population: Plan for Implementation (HAPPI2) (Housing Our Ageing Population Panel for Innovation, 2012: 12).

Consequently, this scoping review mapped, rather than synthesised, the evidence (Chang, 2018) and the findings are used to assess the implications for policy/practice rather than making recommendations (Munn et al., 2018).

For the purposes of this scoping review, the home environment was defined as the physical setting and its immediate environment including outdoor spaces, such as the garden or balcony. The type of residence was mainstream (everyday) and specialised housing as categorised in Housing Our Ageing Population: Plan for Implementation (HAPPI2) (Housing Our Ageing Population Panel for Innovation, 2012) and this is illustrated in Figure 1. The HAPPI2 Care Home categories were excluded from the review.

We found it challenging to define 'adaptation' in the context of this scoping review as there is inconsistency between the phrases 'adaptation' and 'modification' and both phrases are used interchangeably in the literature depending upon geographical location and the type of intervention. In this scoping review, therefore, adaptation is defined as 'alterations to the permanent physical environment' and accounts for the scoping review inclusion criteria.

\section{Method}

It is widely acknowledged that there has been considerable disparity in both the methodological conduct and reporting quality of scoping reviews (Colquhoun et al., 2014; Tricco et al., 2016). In response, and based on the seminal work of Arskey and O'Malley (2005) and Levac et al. (2010), the Joanna Briggs Institute recently published guidance on methodological conduct of scoping reviews to ensure standardisation and measurable compliance (Peters et al., 2015). The 
underpinning methodology for this scoping review therefore adheres to the guidance provided by Peters et al. $(2015,2017)$.

The development of the inclusion criteria followed the 'PCC' mnemonic (Population, Concept, Context) (Peters et al., 2017). Studies were not excluded on the basis of study design, and by including diverse forms of evidence from different types of research (qualitative/quantitative/mixed methods), the findings from the review have the potential to inform policy and practice (Peters et al., 2017). Additionally, due to a paucity of research on home adaptations, no date limits were set on the search. The finalised inclusion criteria are summarised in Table 1.

An initial exploratory search was undertaken using CINAHL, Google Scholar and Web of Science Core Collection (Bramer et al., 2017). Three sets of search terms were used on the basis of Participant/Concept/Context, thereby aligning the search terms with the inclusion criteria. The search terms are shown in Table 2.

The main literature search was informed by previous systematic reviews specific to home adaptations, and the need to include specialist databases (Bramer et al., 2017) relevant to housing in addition to health and social care. Eight databases were selected so as to avoid overlap: Allied and Complimentary Medicine (AMED), Applied Social Science Index and Abstracts (ASSIA), Cumulative Index to Nursing and Allied Health Literature (CINAHL PLUS), Design and Applied Arts Index, genHOME Repository, Health Management Information Consortium (HMIC), MEDLINE, and Social Policy and Practice. Using the search terms shown in Table 2, each database was searched separately (Booth, 2016).

However, it is possible that studies may still be missed so the accepted practice of using complimentary search methods was important in compensating for such deficiencies (Papaionnou et al., 2010), and this comprised three approaches. Firstly, reference list checking of the included studies was utilised because it is suggested that this is 'simply good practice' (Booth et al., 2016: 16). Second, the Web of Science Citation Index was additionally used for citation reference searching to see where eligible studies had later been cited in case this identified any additional studies. Third, hand searches were undertaken of salient journals (Britten and Pope, 2012), namely Dementia: The International Journal of Social Science Research and Practice and The Journal of Housing for the Elderly (renamed Journal of Aging and Environment from 2020).

The selection of studies was undertaken based on the pre-specified inclusion criteria and two-stage screening practice (title and abstract, full-text) and the results of this are illustrated in Figure 2.

The scoping review included 13 papers, and these constitute the included studies as illustrated in Figure 1. Data extraction comprised the characteristics of included studies and a narrative summary, as shown in Table 3.

In summarising Table 3, six papers were published in the 1990s (all from the United States of America (USA)) and seven papers were published more recently, including four from the USA and three from the UK. No papers from the UK were published prior to 2017. In describing the demographic data of the participants, it is important to note that there is a compounding factor as two US papers (Olsen et al., 1993, 1996) and two UK papers (Soilemezi, 2017a, 2017b) were from the same set of interviews. This means that there are 11 sets of interview participants in total instead of 13 sets, due to double-counting. For the 11 sets of participants, 
Table 1. Inclusion criteria

\begin{tabular}{|c|c|c|}
\hline Aspect & Inclusion criteria & Exclusion criteria \\
\hline Population & $\begin{array}{l}\text { People with dementia (including } \\
\text { Alzheimer's disease) who may/may } \\
\text { not have a formal diagnosis, or } \\
\text { family carers speaking on behalf of } \\
\text { a person with dementia }\end{array}$ & $\begin{array}{l}\text { People who do not have dementia } \\
\text { (including Alzheimer's disease), and } \\
\text { family carers not speaking on behalf of } \\
\text { a person with dementia }\end{array}$ \\
\hline Concept & $\begin{array}{l}\text { Adaptations/modifications - } \\
\text { defined as alterations to the } \\
\text { permanent physical environment }\end{array}$ & $\begin{array}{l}\text { - Everyday technologies such as a } \\
\text { telephone } \\
\text { - Assistive devices such as a } \\
\text { falls-pendants } \\
\text { - Assistive equipment such as } \\
\text { wheelchairs and walkers } \\
\text { - Information and communications } \\
\text { technology-based services including } \\
\text { telehealth and telecare }\end{array}$ \\
\hline Context & $\begin{array}{l}\text { - Living in the community in } \\
\text { mainstream (everyday) or } \\
\text { specialised housing including } \\
\text { sheltered, extra-care, assisted } \\
\text { living, retirement accommodation } \\
\text { - All tenures including renting; } \\
\text { living alone or with others (such } \\
\text { as family care-givers) }\end{array}$ & $\begin{array}{l}\text { - Living in communal facilities such as } \\
\text { long-term care including residential } \\
\text { homes, nursing homes, specialised } \\
\text { care homes, specifically designed } \\
\text { dementia units, hospital } \\
\text { - New housing designed (rather than } \\
\text { adapted/modified) for dementia } \\
\text { - Virtual reality spaces including homes }\end{array}$ \\
\hline $\begin{array}{l}\text { Types of } \\
\text { studies }\end{array}$ & $\begin{array}{l}\text { - Studies that meet the inclusion } \\
\text { criteria (including qualitative, } \\
\text { quantitative and mixed methods) } \\
\text { - Studies published in English }\end{array}$ & $\begin{array}{l}\text { - Systematic (and other) reviews } \\
\text { - Research protocols, conference } \\
\text { abstracts and editorials } \\
\text { - Grey literature including adaptation } \\
\text { design guidelines } \\
\text { - Studies published in languages other } \\
\text { than English } \\
\text { - Studies where it is not possible to } \\
\text { disentangle population groups (i.e. } \\
\text { people living with dementia within a } \\
\text { group of older adults) } \\
\text { - Studies where it is not possible to } \\
\text { disentangle the adaptations from } \\
\text { assistive devices/assistive equipment/ } \\
\text { information and communications } \\
\text { technology services }\end{array}$ \\
\hline
\end{tabular}

data collection was generally undertaken solely with carers $(\mathrm{N}=7)$ with a smaller number of joint interviews between the carer and the person with dementia $(\mathrm{N}=4)$. One study (Mann et al., 1996) included 19 people with dementia and it was unclear if the 16 carers identified in the paper as acting in a supporting capacity were also involved in the interviews. The four studies involving people with dementia as participants (Silverstein et al., 1993; Mann et al., 1996; Marquardt et al., 2011; Allen et al., 2019) included a total of 140 participants. Additionally, studies where the participant was a carer often provided details of the person they cared for even though they were not included directly in the study. An overview of stage and type of dementia is not summarised in this scoping review as there are missing data and 
Table 2. Search terms

\begin{tabular}{lll}
\hline S1 & Participant & dementia* OR alzheimer ${ }^{\star}$ OR neurodegeneration \\
AND & & \\
S2 & Concept & adaptation ${ }^{*}$ OR modification \\
\hline AND & Context & home $^{*}$ OR dwelling \\
S3 & & \\
\hline
\end{tabular}

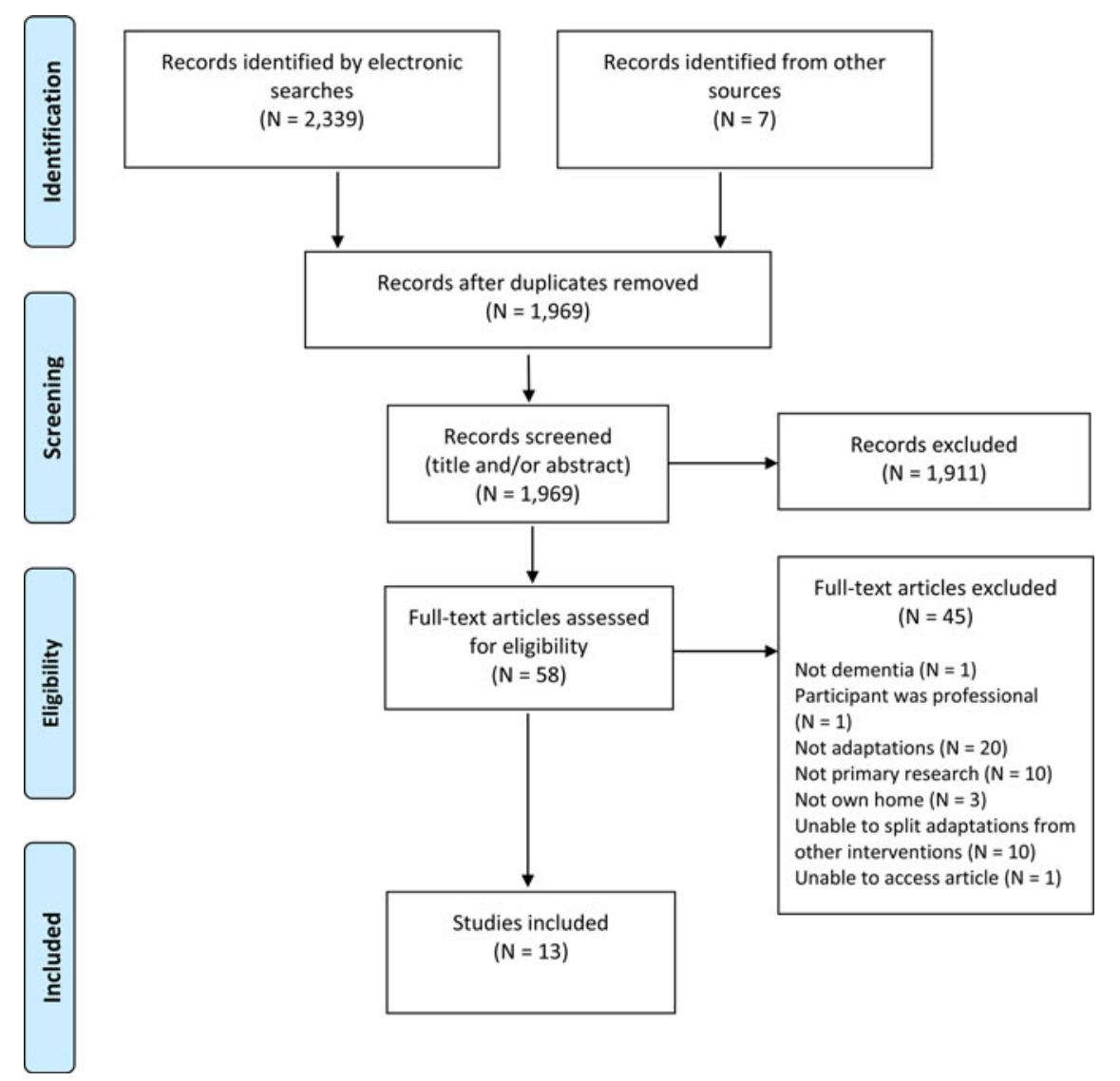

Figure 2. PRISMA flow diagram (Moher et al., 2009).

a lack of consistency across the included studies. However, individual data, where available, are provided in Table 3. The total number of carers involved in the studies was 367 . Spouses comprised the main carers $(\mathrm{N}=204)$, followed by adult children $(\mathrm{N}=130)$, with a small number of 'other' $(\mathrm{N}=33)$ which were largely undefined. The two UK studies comprised eight people with dementia and 23 carers. 
Table 3. Characteristics of included studies

\begin{tabular}{|c|c|c|c|c|c|c|c|}
\hline Study ID & ID 1 & ID 2 & ID 3 & ID 4 & ID 5 & ID 6 & ID 7 \\
\hline Author & Allen et al. (2019) & $\begin{array}{l}\text { Anderson and Rose } \\
\text { (2019) }\end{array}$ & $\begin{array}{l}\text { Calkins and } \\
\text { Namazi (1991) }\end{array}$ & $\begin{array}{l}\text { Damme and } \\
\text { Ray-Degges (2016) }\end{array}$ & $\begin{array}{l}\text { Lach and Chang } \\
(2007)\end{array}$ & Mann et al. (1996) & $\begin{array}{l}\text { Marquardt et al. } \\
\text { (2011) }\end{array}$ \\
\hline Journal & Dementia & $\begin{array}{l}\text { Journal of } \\
\text { Gerontological Nursing }\end{array}$ & $\begin{array}{l}\text { American } \\
\text { Journal of } \\
\text { Alzheimer's Care } \\
\text { and Related } \\
\text { Disorders \& } \\
\text { Research }\end{array}$ & $\begin{array}{l}\text { Journal of Housing } \\
\text { for the Elderly }\end{array}$ & $\begin{array}{l}\text { Western Journal of } \\
\text { Nursing Research }\end{array}$ & $\begin{array}{l}\text { Topics in Geriatric } \\
\text { Rehabilitation }\end{array}$ & $\begin{array}{l}\text { Journal of } \\
\text { Housing for the } \\
\text { Elderly }\end{array}$ \\
\hline Country & UK & Western countries & USA & USA & USA & USA & USA \\
\hline $\begin{array}{l}\text { Focus of the } \\
\text { study that is } \\
\text { relevant to } \\
\text { scoping } \\
\text { review }\end{array}$ & $\begin{array}{l}\text { The experiences of } \\
\text { PWD and their } \\
\text { carer's in adapting } \\
\text { the home }\end{array}$ & $\begin{array}{l}\text { Non-pharmacological } \\
\text { strategies to } \\
\text { understand acceptable } \\
\text { targets for intervention } \\
\text { development and } \\
\text { testing }\end{array}$ & $\begin{array}{l}\text { Identify the } \\
\text { variety of } \\
\text { modifications, } \\
\text { ascertain } \\
\text { effectiveness } \\
\text { and evaluate } \\
\text { impact }\end{array}$ & $\begin{array}{l}\text { Care-giver } \\
\text { perceptions on the } \\
\text { effect of the home } \\
\text { environment on } \\
\text { independence of } \\
\text { PWD }\end{array}$ & $\begin{array}{l}\text { Experience of } \\
\text { care-givers in } \\
\text { developing } \\
\text { interventions to } \\
\text { provide safe care }\end{array}$ & $\begin{array}{l}\text { Changes over } \\
\text { time ( } 1 \text { year) in } \\
\text { implementation } \\
\text { and use of } \\
\text { assistive devices } \\
\text { and home } \\
\text { modifications }\end{array}$ & $\begin{array}{l}\text { Detailed } \\
\text { description of } \\
\text { common } \\
\text { environmental } \\
\text { features and } \\
\text { home } \\
\text { modifications }\end{array}$ \\
\hline $\begin{array}{l}\text { Type of } \\
\text { study } \\
\text { (design) }\end{array}$ & $\begin{array}{l}\text { Qualitative - } \\
\text { interpretative } \\
\text { phenomenological } \\
\text { approach }\end{array}$ & Qualitative & Qualitative & $\begin{array}{l}\text { Qualitative - } \\
\text { phenomenological } \\
\text { approach }\end{array}$ & Qualitative & Mixed methods & $\begin{array}{l}\text { Randomised } \\
\text { controlled trial }\end{array}$ \\
\hline Participants & $\begin{array}{l}18 \text { participants in } \\
\text { total; } 8 \text { PWD + } \\
\text { family carers; } 2 \\
\text { family carers }\end{array}$ & 9 care-givers & 59 care-givers & 6 family care-givers & $\begin{array}{l}39 \text { family } \\
\text { care-givers }\end{array}$ & $\begin{array}{l}19 \text { people with } \\
\text { Alzheimer's } \\
\text { disease (unclear } \\
\text { whether carer } \\
\text { involved in } \\
\text { interview) }\end{array}$ & $\begin{array}{l}82 \text { PWD + } \\
\text { care-givers } \\
\text { (subset cohort) }\end{array}$ \\
\hline $\begin{array}{l}\text { Age and } \\
\text { gender }\end{array}$ & $\begin{array}{l}\text { PWD - mean age } \\
73.2 ; 2 \text { females, } 6 \\
\text { males; carers - } \\
\text { mean age } 61.3 ; 6 \\
\text { females, } 4 \text { males }\end{array}$ & $\begin{array}{l}\text { Age not provided; } 8 \\
\text { females, } 1 \text { male }\end{array}$ & $\begin{array}{l}\text { Mean age } 59.5 ; \\
46 \text { females, } 13 \\
\text { males }\end{array}$ & $\begin{array}{l}\text { Mean age } 63 ; 4 \\
\text { females, } 2 \text { males }\end{array}$ & $\begin{array}{l}\text { Mean age not } \\
\text { provided; } 28 \\
\text { females, } 11 \text { males }\end{array}$ & $\begin{array}{l}\text { Mean age } 78.9 ; 10 \\
\text { females, } 9 \text { males }\end{array}$ & $\begin{array}{l}\text { PWD - mean } \\
\text { age } 84.5 ; 51 \\
\text { females, } 31 \\
\text { males; } \\
\text { care-givers' age } \\
\text { and gender not } \\
\text { provided }\end{array}$ \\
\hline
\end{tabular}


Table 3. (Continued.)

\begin{tabular}{|c|c|c|c|c|c|c|c|}
\hline Study ID & ID 1 & ID 2 & ID 3 & ID 4 & ID 5 & ID 6 & ID 7 \\
\hline $\begin{array}{l}\text { Stage of } \\
\text { dementia }\end{array}$ & $\begin{array}{l}2 \text { months to } 4 \text { years } \\
\text { since diagnosis; } \\
\text { range of dementia } \\
\text { type }\end{array}$ & Not provided & $\begin{array}{l}\text { Average } \\
\text { duration of } \\
\text { condition } 6 \\
\text { years }\end{array}$ & Not provided & $\begin{array}{l}15 \text { PWD very mild } \\
\text { dementia (CDR 0.5); } \\
15 \text { PWD mild } \\
\text { dementia (CDR } 1.0 \text { ); } \\
11 \text { PWD moderate } \\
\text { dementia (CDR 2.0) }\end{array}$ & $\begin{array}{l}\text { MMSE score of } \\
\text { less than 24; } \\
\text { diagnosis of } \\
\text { Alzheimer's } \\
\text { disease }\end{array}$ & $\begin{array}{l}36 \text { mild } \\
\text { dementia } \\
\text { (MMSE } 21 \text { and } \\
\text { above); } 31 \\
\text { moderate } \\
\text { dementia } \\
\text { (MMSE 11-20); } \\
14 \text { severe } \\
\text { dementia } \\
\text { (MMSE 0-10) }\end{array}$ \\
\hline $\begin{array}{l}\text { Type of } \\
\text { carer }\end{array}$ & 9 spouses, 1 child & 2 spouses, 7 children & $\begin{array}{l}26 \text { spouses, } 30 \\
\text { children (or } \\
\text { in-law), } 1 \\
\text { sibling, } 2 \text { others }\end{array}$ & $\begin{array}{l}3 \text { wives, } 1 \text { brother, } 2 \\
\text { children }\end{array}$ & $\begin{array}{l}24 \text { wives, } 10 \\
\text { husbands, } 4 \\
\text { daughters, } 1 \text { son; } \\
\text { mean caring } \\
\text { duration } 5.8 \text { years }\end{array}$ & $\begin{array}{l}\text { (care-giver } \\
\text { mentioned but } \\
\text { unclear whether } \\
\text { involved in the } \\
\text { interview); mean } \\
\text { age } 63.9 ; 11 \\
\text { females, } 5 \text { males } \\
(\mathrm{N}=16) ; 8 \\
\text { spouses, } 7 \\
\text { relatives, } 1 \text { paid } \\
\text { carer }(\mathrm{N}=16)\end{array}$ & $\begin{array}{l}36 \text { spouses, } 30 \\
\text { children, } 16 \\
\text { others }\end{array}$ \\
\hline $\begin{array}{l}\text { Concept } \\
\text { (HA/HM) }\end{array}$ & $\begin{array}{l}\text { Adapting the home } \\
\text { (adding, taking } \\
\text { away, changing, } \\
\text { different rooms, } \\
\text { outside) }\end{array}$ & $\begin{array}{l}\text { Modifying the physical } \\
\text { environment (one of a } \\
\text { number of strategies) }\end{array}$ & $\begin{array}{l}\text { Broad definition } \\
\text { of HM 'any } \\
\text { change made } \\
\text { for the safety, } \\
\text { security, or } \\
\text { comfort of } \\
\text { PWD, and/or as } \\
\text { a change that } \\
\text { makes } \\
\text { caregiving } \\
\text { easier' }\end{array}$ & $\begin{array}{l}\text { Mixed range of } \\
\text { questions on } A D L \\
\text { with specific } \\
\text { questions on } \\
\text { changes to the } \\
\text { home environment. } \\
\text { No formal definition }\end{array}$ & $\begin{array}{l}\text { Safety problems } \\
\text { and management } \\
\text { strategies } \\
\text { (including changes } \\
\text { to the home). List } \\
\text { of focus group } \\
\text { prompts not } \\
\text { provided. No formal } \\
\text { definition }\end{array}$ & $\begin{array}{l}\text { Assistive devices/ } \\
\text { technologies used } \\
\text { in the home, but } \\
\text { definition } \\
\text { includes HA/HM }\end{array}$ & $\begin{array}{l}\text { Home } \\
\text { modifications } \\
\text { (narrow) } \\
\text { definition }\end{array}$ \\
\hline
\end{tabular}


Table 3. (Continued.)

\begin{tabular}{|c|c|c|c|c|c|c|c|}
\hline Study ID & ID 1 & ID 2 & ID 3 & ID 4 & ID 5 & ID 6 & ID 7 \\
\hline $\begin{array}{l}\text { Context - } \\
\text { housing } \\
\text { type }\end{array}$ & $\begin{array}{l}\text { Everyday housing - } \\
\text { range of housing } \\
\text { types, occupancy } \\
\text { length and } \\
\text { locations }\end{array}$ & $\begin{array}{l}\text { Inference is everyday } \\
\text { housing }\end{array}$ & $\begin{array}{l}\text { Everyday } \\
\text { housing }\end{array}$ & Everyday housing & $\begin{array}{l}\text { Not provided, but it } \\
\text { does exclude } \\
\text { institutionalisation }\end{array}$ & Everyday housing & $\begin{array}{l}\text { Everyday } \\
\text { housing }\end{array}$ \\
\hline $\begin{array}{l}\text { Data } \\
\text { collection } \\
\text { method }\end{array}$ & $\begin{array}{l}\text { Semi-structured } \\
\text { joint interview } \\
\text { (both PWD + carer) } \\
\text { in the home }\end{array}$ & $\begin{array}{l}2,345 \text { posts from nine } \\
\text { blogs }\end{array}$ & $\begin{array}{l}\text { Telephone } \\
\text { interviews }\end{array}$ & $\begin{array}{l}\text { Semi-structured } \\
\text { face-to-face } \\
\text { interviews with } 5 \\
\text { care-givers at home } \\
\text { and } 1 \text { care-giver at } \\
\text { place of } \\
\text { employment }\end{array}$ & $\begin{array}{l}\text { Six focus groups } \\
\text { including using } \\
\text { standard checklists }\end{array}$ & $\begin{array}{l}\text { Interview at } \\
\text { home, and then } \\
\text { second interview } \\
\text { at home } 1 \text { year } \\
\text { later. Range of } \\
\text { quantitative data } \\
\text { collected to } \\
\text { measure change } \\
\text { in health, mental } \\
\text { and functional } \\
\text { status between } \\
\text { the two visits, and } \\
\text { descriptive data } \\
\text { collection of } \\
\text { home } \\
\text { modifications }\end{array}$ & $\begin{array}{l}\text { Home } \\
\text { environment } \\
\text { walk-through } \\
\text { and } \\
\text { questionnaire }\end{array}$ \\
\hline Analysis & $\begin{array}{l}\text { Interpretive } \\
\text { phenomenological } \\
\text { analysis }\end{array}$ & Thematic analysis & Not provided & Thematic analysis & $\begin{array}{l}\text { General description } \\
\text { but methods not } \\
\text { explicitly stated }\end{array}$ & Paired $t$-tests & Not provided \\
\hline
\end{tabular}


Table 3. (Continued.)

\begin{tabular}{|c|c|c|c|c|c|c|}
\hline Study ID & ID 8 & ID 9 & ID 10 & ID 11 & ID 12 & ID 13 \\
\hline Author & Olsen et al. (1993) & Olsen et al. (1996) & $\begin{array}{l}\text { Pynoos and Ohta } \\
\text { (1991) }\end{array}$ & Silverstein et al. (1993) & $\begin{array}{l}\text { Soilemezi et al. } \\
(2017 a)\end{array}$ & $\begin{array}{l}\text { Soilemezi et al. } \\
(2017 b)\end{array}$ \\
\hline Journal & $\begin{array}{l}\text { Technology and } \\
\text { Disability }\end{array}$ & $\begin{array}{l}\text { Topics in Geriatric } \\
\text { Rehabilitation }\end{array}$ & $\begin{array}{l}\text { Physical and } \\
\text { Occupational Therapy } \\
\text { in Geriatrics }\end{array}$ & $\begin{array}{l}\text { Technology and } \\
\text { Disability }\end{array}$ & $\begin{array}{l}\text { Journal of } \\
\text { Environmental } \\
\text { Psychology }\end{array}$ & $\begin{array}{l}\text { Journal of Housing for } \\
\text { the Elderly }\end{array}$ \\
\hline Country & USA & USA & USA & USA & UK & UK \\
\hline $\begin{array}{l}\text { Focus of the } \\
\text { study that is } \\
\text { relevant to } \\
\text { scoping } \\
\text { review }\end{array}$ & $\begin{array}{l}\text { Care-givers' use of } \\
\text { home modifications to } \\
\text { problem solve and } \\
\text { effectiveness }\end{array}$ & $\begin{array}{l}\text { Care-givers' use of } \\
\text { home } \\
\text { modifications and } \\
\text { technology }\end{array}$ & $\begin{array}{l}\text { Effectiveness of } \\
\text { interventions in the } \\
\text { home }\end{array}$ & $\begin{array}{l}\text { Care-givers' } \\
\text { implementation of } \\
\text { professional } \\
\text { recommendations } \\
\text { regarding home } \\
\text { adaptation }\end{array}$ & $\begin{array}{l}\text { Exploring the meaning } \\
\text { of home for family } \\
\text { care-givers of PWD }\end{array}$ & $\begin{array}{l}\text { The impact of the } \\
\text { physical home } \\
\text { environment for family } \\
\text { carers of PWD }\end{array}$ \\
\hline $\begin{array}{l}\text { Type of study } \\
\text { (design) }\end{array}$ & Qualitative & Qualitative & $\begin{array}{l}\text { Qualitative - } \\
\text { intervention study }\end{array}$ & Qualitative & $\begin{array}{l}\text { Qualitative - } \\
\text { phenomenological } \\
\text { approach }\end{array}$ & $\begin{array}{l}\text { Qualitative - } \\
\text { phenomenological } \\
\text { approach }\end{array}$ \\
\hline Participants & $\begin{array}{l}90 \text { family care-givers } \\
\text { (same as Olsen et al., } \\
\text { 1996) }\end{array}$ & $\begin{array}{l}90 \text { family } \\
\text { care-givers (same } \\
\text { as Olsen et al., } \\
1993 \text { ) }\end{array}$ & $\begin{array}{l}12 \text { family care-givers; } \\
11 \text { spouses, } 1 \text { adult } \\
\text { child }\end{array}$ & $\begin{array}{l}31 \text { Alzheimer } \\
\text { households ( } 26 \text { at end of } \\
\text { study) }\end{array}$ & $\begin{array}{l}13 \text { co-resident carers } \\
\text { (same interviews as } \\
\text { Soilemezi et al. } \\
(2017 b)\end{array}$ & $\begin{array}{l}13 \text { co-resident carers } \\
\text { (same interviews as } \\
\text { Soilemezi et al. } \\
(2017 a)\end{array}$ \\
\hline $\begin{array}{l}\text { Age and } \\
\text { gender }\end{array}$ & $\begin{array}{l}\text { Mean age not } \\
\text { provided; } 60 \text { females, } \\
30 \text { males; } 46 \text { spouses, } \\
41 \text { children, } 3 \text { others; } \\
\text { mean duration of } \\
\text { care-giving } 6 \text { years }\end{array}$ & $\begin{array}{l}\text { Not provided; } \\
\text { mention of 'long } \\
\text { term' }\end{array}$ & $\begin{array}{l}\text { Mean age } 70.8 ; 7 \\
\text { female, } 5 \text { male; mean } \\
\text { duration of } \\
\text { care-giving } 40.1 \\
\text { months }\end{array}$ & $\begin{array}{l}\text { Mean age } 78.6 ; 20 \\
\text { female, } 11 \text { male }\end{array}$ & $\begin{array}{l}1 \text { carer } 50-59,8 \text { carers } \\
60-69,3 \text { carers } 70-79 \text {, } \\
1 \text { carer } 80-89 ; 9 \\
\text { females, } 4 \text { males }\end{array}$ & $\begin{array}{l}1 \text { carer } 50-59,8 \text { carers } \\
60-69,3 \text { carers } 70-79 \text {, } \\
1 \text { carer } 80-89 ; 9 \\
\text { females, } 4 \text { males }\end{array}$ \\
\hline
\end{tabular}


Table 3. (Continued.)

\begin{tabular}{|c|c|c|c|c|c|c|}
\hline Study ID & ID 8 & ID 9 & ID 10 & ID 11 & ID 12 & ID 13 \\
\hline $\begin{array}{l}\text { Stage of } \\
\text { dementia }\end{array}$ & $\begin{array}{l}43 \text { PWD living at } \\
\text { home, } 24 \text { living in } \\
\text { nursing home, } 23 \\
\text { deceased }\end{array}$ & Not provided & $\begin{array}{l}\text { Formal diagnosis of } \\
\text { Alzheimer's disease; } \\
\text { mean age of PWD } \\
77.3 \text {; ADL score } \\
\text { average } 16.9 \text { (possible } \\
\text { range } 8-48 \text { with } \\
\text { higher scores } \\
\text { indicating greater } \\
\text { impairment); } \\
\text { instrumental ADL } \\
\text { score average } 37.2 \\
\text { (possible range } 8-46 \\
\text { ditto) }\end{array}$ & $\begin{array}{l}\text { Moderate to severe; } 9 \\
\text { PWD institutionalised by } \\
\text { the end of the study }\end{array}$ & $\begin{array}{l}\text { Not provided but had } \\
\text { capacity to consent }\end{array}$ & $\begin{array}{l}\text { Not provided but had } \\
\text { capacity to consent }\end{array}$ \\
\hline Type of carer & $\begin{array}{l}\mathrm{N} / \mathrm{A} \text { because carer is } \\
\text { participant }\end{array}$ & $\begin{array}{l}\mathrm{N} / \mathrm{A} \text { because carer } \\
\text { is participant }\end{array}$ & $\begin{array}{l}\mathrm{N} / \mathrm{A} \text { because carer is } \\
\text { participant }\end{array}$ & $\begin{array}{l}\text { Mean age } 63 \text { years; } 19 \\
\text { female, } 12 \text { male; } 17 \\
\text { spouses, } 1 \text { sibling, } 12 \\
\text { children, } 1 \text { nephew; } \\
\text { mean duration of } \\
\text { care-giving } 3.8 \text { years }\end{array}$ & $\begin{array}{l}12 \text { spouses, } 1 \text { child; } 10 \\
\text { carers had been caring } \\
\text { for } 0-5 \text { years, } 3 \text { carers } \\
\text { for } 6-10 \text { years }\end{array}$ & $\begin{array}{l}12 \text { spouses, } 1 \text { child; } 10 \\
\text { carers had been caring } \\
\text { for } 0-5 \text { years, } 3 \text { carers } \\
\text { for } 6-10 \text { years }\end{array}$ \\
\hline $\begin{array}{l}\text { Concept (HA/ } \\
\text { HM) }\end{array}$ & $\begin{array}{l}\text { Mix of assistive } \\
\text { devices/HM - both } \\
\text { defined as HM }\end{array}$ & $\begin{array}{l}\text { Mix of assistive } \\
\text { devices/HM - both } \\
\text { defined as HM }\end{array}$ & Wide definition of HA & $\begin{array}{l}\text { Wide definition of HA } \\
\text { under four categories - } \\
\text { cognitive or behavioural } \\
\text { impairment, safety, } \\
\text { care-giver ease, } \\
\text { impairment in ADL }\end{array}$ & $\begin{array}{l}\text { Specific modifications } \\
\text { to the physical } \\
\text { environment }\end{array}$ & $\begin{array}{l}\text { Different aspects of } \\
\text { the home including } \\
\text { environmental } \\
\text { strategies }\end{array}$ \\
\hline $\begin{array}{l}\text { Context - } \\
\text { housing type }\end{array}$ & $\begin{array}{l}\text { Everyday housing - } \\
\text { range of } \\
\text { neighbourhoods and } \\
\text { dwelling types }\end{array}$ & $\begin{array}{l}\text { Everyday housing - } \\
\text { range of } \\
\text { neighbourhoods } \\
\text { and dwelling types }\end{array}$ & Everyday housing & $\begin{array}{l}\text { Everyday housing, } 22 \\
\text { owned home, } 9 \text { renting }\end{array}$ & $\begin{array}{l}\text { Everyday housing - } \\
\text { range of property type } \\
\text { and duration of } \\
\text { residence }\end{array}$ & $\begin{array}{l}\text { Everyday housing - } \\
\text { range of property type } \\
\text { and duration of } \\
\text { residence }\end{array}$ \\
\hline
\end{tabular}

(Continued) 
Table 3. (Continued.)

\begin{tabular}{|c|c|c|c|c|c|c|}
\hline Study ID & ID 8 & ID 9 & ID 10 & ID 11 & ID 12 & ID 13 \\
\hline $\begin{array}{l}\text { Data } \\
\text { collection } \\
\text { method }\end{array}$ & $\begin{array}{l}\text { In-depth interviews, } \\
\text { the majority were } \\
\text { conducted in the } \\
\text { home }\end{array}$ & In-depth interviews & $\begin{array}{l}\text { Demographic } \\
\text { information collected } \\
\text { by phone. Home visit } \\
\text { based on the } \\
\text { checklists. } \\
\text { Adaptations } \\
\text { implemented by the } \\
\text { research team and } \\
\text { effectiveness } \\
\text { assessed at 7-month } \\
\text { follow-up }\end{array}$ & $\begin{array}{l}\text { Four phases - interviews } \\
\text { at home and telephone } \\
\text { follow-up }\end{array}$ & $\begin{array}{l}\text { Semi-structured } \\
\text { indoor walking } \\
\text { interviews }\end{array}$ & $\begin{array}{l}\text { Semi-structured } \\
\text { indoor walking } \\
\text { interviews }\end{array}$ \\
\hline $\begin{array}{l}\text { Approach to } \\
\text { analysis }\end{array}$ & Not provided & Not provided & Not provided & $\begin{array}{l}\text { Quantitative analysis of } \\
\text { standard tests, } \\
\text { descriptive analysis of } \\
\text { adaptations }\end{array}$ & Thematic analysis & Thematic analysis \\
\hline
\end{tabular}

Notes: ADL: activities of daily living. CDR: Clinical Dementia Rating. HA: housing adaptation. HM: housing modification. MMSE: Mini-Mental State Examination. N/A: not applicable. PWD: people with dementia. UK: United Kingdom. USA: United States of America. 
The 13 included studies adopted a qualitative methodology, with the exception of one mixed-methods study (Mann et al., 1996) and one study where the participants were a subset of a larger randomised control trial (Marquardt et al., 2011). A wide range of data collection methods were utilised across all the studies, comprising: telephone interviews $(\mathrm{N}=1)$, face-to-face interviews, typically in the home $(\mathrm{N}=10)$, focus groups $(\mathrm{N}=1)$ and blogs $(\mathrm{N}=1)$. Interviews in the home were often supplemented with more diverse and creative methods including home environment assessments, indoor walking interviews and observations. Approach to analysis was often not provided, although the two UK studies used interpretive phenomenological analysis (Allen et al., 2019) and thematic analysis (Soilemezi et al., 2017b).

It should be noted that all 13 included studies presented data on the contribution of home adaptations in supporting everyday life for people with dementia, which is the aim of this scoping review, although it is acknowledged that the extent to which studies did this varied greatly both in terms of breadth and depth. Therefore, the strategy for data synthesis of the 13 included studies comprised thematic analysis using the six-phase approach proposed by Braun and Clarke (2006). Each of the included studies was an individual dataset with a finding being defined as 'a verbatim extract of the author's analytic interpretation of their results or data' (Lockwood et al., 2017: 29). Where possible, each finding was accompanied by an illustration defined as 'a direct quotation of a participant's voice, field-work observation or other supporting data from the paper' (Lockwood et al., 2017: 29). The aim of the coding and the emergent theme development was to provide a coherent and authentic interpretation of the data in response to each of the four scoping review questions. To the best of our knowledge, this is the first time that such a review has been attempted and reported.

\section{Findings}

These are grouped and presented in relation to each of the four scoping review questions, noting that review question 3 is further divided into two parts (3a and $3 b)$.

\section{Scoping review question 1: Which housing adaptations are being implemented and used by people with dementia and their carers on an everyday basis?}

The most common adaptations were recommended and/or implemented to compensate for a person's physical limitations (Soilemezi et al., 2017b; Allen et al., 2019) and for safety reasons (Lach and Chang, 2007). This is consistent with earlier research highlighted by Silverstein et al. (1993) which showed that adaptations to support activities of daily living, including promoting independence, were considerably less likely to be recommended because the emphasis was on a person's physical challenges. For example, in a study by Marquardt et al. (2011) which comprised of 82 households, 48.7 per cent $(\mathrm{N}=37)$ of those households had enhanced bathroom safety to address the physical limitations of the person with dementia. Similarly, each of the 59 carers in the Calkins and Namazi (1991) study had 
made at least one housing modification, including installing a shower or adding grab rails to improve bathroom safety. For personal limitations related to cognition, the solutions in the included studies (e.g. Calkins and Namazi, 1991; Marquardt et al., 2011; Allen et al., 2019) fell within a definition of assistive devices, rather than housing adaptations.

Common housing adaptations are summarised in Table 4 and these have been categorised into two overall headings, namely 'making adjustments' and 'modifying how the space is used'. Whilst it is also good practice to provide accompanying participant quotes, these were very sparse within the included studies and hence the reliance on a limited number of authors.

\section{Scoping review question 2: How are decisions made to implement and use housing adaptations, or otherwise?}

Successful home modification strategy is an ongoing process (Olsen et al., 1996), and it appeared to be a mix of professional advice and trial and error. Additionally, Anderson and Rose (2019), through their analysis of carer blogs, found that online information, either through reading other blogs or carer discussion forums, were important in personal decision making. In terms of professional advice, there are nuances in language such that within the UK, advice was typically provided by an occupational therapist (Allen et al., 2019) whereas in the USA, home health services, or community-based services (Damme and Ray-Degges, 2016), often advised on modifications. In two of the included studies (Pynoos and Ohta, 1991; Marquardt et al., 2011), decisions to implement and use adaptations were made on the advice of a research team in consultation with professionals. Furthermore, carers often initiated interventions either through trial and error or inadvertently (Marquardt et al., 2011; Soilemezi et al., 2017b; Allen et al., 2019). As an example, in some bathrooms, grab bars and non-skid bathmats were used after consultation with a physical or occupational therapist. In others, grab bars from hardware stores were installed on the basis of the carer's knowledge alone, without professional input (Marquardt et al., 2011).

\section{Scoping review question 3a: What are the barriers to housing adaptation implementation and use?}

Access to information

Both Marquardt et al. (2011) and Allen et al. (2019) identified the difficulties of accessing information on home adaptations specific to dementia, and of not having been given relevant information in the first place. Specifically, Marquardt et al. (2011) found that households were three times more likely to make modifications for physical limitations rather than memory loss. The most likely reason for this was lack of knowledge about the symptoms of dementia and how these differ from physical symptoms. Information on the potential benefits of adaptations was not readily available, despite carers being keen to 'give it a go'.

Professional advice was readily available yet carers expressed reservations about the involvement of health and social care professionals in their lives, believing that 
Table 4. Common housing adaptations

Making adjustments:

- Limiting or controlling access through disguising passageways and off-limit areas, changes to locks and doorknobs (including adding to and taking away): 'We had come back from shopping and I used the bathroom behind the garage so she had to use the bathroom in the bedroom ... Anyway she opened the wrong door and fell down the basement stairs ... So I put a latch on that door' (Lach and Chang, 2007: 1001).

- Changes to radiators either to control the temperature or to provide a radiator cover.

- Flooring - carpets (comfort and warmth) versus hard flooring (cleanliness), eliminating shiny surfaces. One carer removed the existing lino flooring because her mother thought it was cold: 'She wouldn't go in on the floor because it was white and she thought it was marble and cold' (Soilemezi et al., 2017b: 312).

- Stairs - additional handrailing, stair lifts, making the stair nosings (edge of stairs) more obvious, restricting stair access with the use of stairgates: 'Very helpful; I just wouldn't be able to cope. Because l'd be forever sort of glued to my wife, all the time ... it gives her more independence ... which I think makes, helps her dignity as well ... I used to have to just follow her up ... It was more sort of a confidence booster for the wife than it was anything else. But the stair lift is ideal because ... it gives her more independence' (Soilemezi et al., 2017b: 316).

- Changes to the immediate outside environment such as putting a handrail on external steps, replacing external steps with a wheelchair ramp, new decking with wind-proofing, providing secure fencing to deter wandering, making the porch all-year-round, screening off the porch to prevent wandering whilst providing opportunity to 'still enjoy and smile at people on the beach' (Olsen et al., 1996: 5).

- Use of colour to improve aesthetics but also to improve carers' mood: 'First colour l've introduced it to my bedroom ... I think I'm trying to lighten my life ... This is the first time I've actually added colour' (Soilemezi et al., 2017b: 312). Another example was repainting bathroom walls a darker colour because the person with dementia 'cannot see a white toilet that is on a white wall' (Anderson and Rose, 2019: 27).

Modifying how the space is used:

- Creating open spaces, including knocking down walls between rooms to allow for direct observation.

- Creating an escape room for carers: 'I am going to make a couple of rooms here very much my own, and the room upstairs is going to be quite important ... I hear young mothers talking about that, they start feeling that they are only someone's mum and they are not an individual anymore, I think it's the same thing, I think you need space ... on the bad days, you need them [separate rooms] so you can comfort yourself' (Soilemezi et al., 2017a: 75).

- Installing a downstairs toilet: 'Probably thinking about it, we've had less accidents since that [toilet's] been there [downstairs] because it's not too far to go' (Soilemezi et al., 2017b: 310).

- Bathrooms - changes included the provision of a walk-in shower with non-slip flooring, bidet, door reversal, bath lift, grab rails: 'The shower's made an awful lot easier ... that's more practical ... It's brilliant ... You got the whole length of it, so it's a lot safer. He's not gonna fall so much' (Soilemezi et al., 2017b: 319).

- Repurposing rooms such that play rooms and dining rooms become bedrooms either for person with dementia or carer, and moving a bedroom downstairs, converting the bedroom into a sitting room for the carer: 'We moved Mom, the lift, and even the mattress into the family room where there is a fire-place so she can stay warm' (Anderson and Rose, 2019: 27).

they would neither be helpful (Lach and Chang, 2007) nor offer adequate support. This was best illustrated in the work of Soilemezi et al. and the carer statement that:

I don't think the social worker has any idea about modifications, she's only a young girl, or there will be a long wait, as in, it would take so long to come out to assess you. (Soilemezi et al., 2017b: 320) 
Silverstein et al. (1993) also found that the carer and professional may not always agree on the underlying reason for the recommendations. Similarly, some carers implemented modifications themselves through trial and error (Soilemezi et al., 2017b).

Despite the difficulties of not having readily accessible information, some carers expressed a reluctance to access information about the future of living with dementia:

I don't want to know about anything in the future cos then you would go mad. (Allen et al., 2019: 8)

Previously, Silverstein et al. (1993) had also found that there was a frustration with some carers who denied that their family member with dementia would further 'deteriorate' and recommended that in such circumstances, a professional role would be to provide individualised and phased advice on home adaptations.

\section{When to make changes?}

Timing of advice and implementation of interventions is complex. This was highlighted by Soilemezi et al. (2017b) who found a tension between carers who thought that changes should be made early in the lived trajectory of dementia as opposed to those who thought that changes should be made only when necessary. As an illustration, Pynoos and Ohta (1991) shared an example of a bidet being ineffective because it was incorporated 'too late' for the person with dementia to adapt to it. Similarly, safety was also noted and Lach and Chang (2007) found that falls often resulted in modifications, with most participants feeling that they would have made changes sooner had they been more aware of the potential risks.

Problems that carers encountered changed continually over time so individualised solutions were necessary especially since each care-giving situation and environment was unique (Olsen et al., 1993). Additionally, Silverstein et al. (1993) picked up on the issue that an adaptation being used to support a person with dementia may have been recommended to address a different target problem. The literature also revealed that carers were often reluctant to make changes to the home if these would cause confusion or irritation to the person with dementia (Marquardt et al., 2011). This was identified by Damme and Ray-Degges who stated that:

It causes confusion when you change things around ... show me that it is going to improve her [mother] mood before I change it because any change we make causes major confusion. (Damme and Ray-Degges, 2016: 100)

Soilemezi et al. also shared an example of a carer who thought that making changes would make the environment more complicated for the person with dementia:

I have thought about having a stair lift but that could be dangerous with him cos he wouldn't know how to work it. (Soilemezi et al., 2017b: 320) 


\section{Carer resistance}

Across the studies, examples were provided of resistance to change by carers and to take on board recommendations for home adaptations provided by professionals. Barriers seemed to be rooted in carer's acceptance of the suggestions which they often perceived as neither necessary nor useful, or quite simply believing that they would not work (Silverstein et al., 1993; Lach and Chang, 2007; Marquardt et al., 2011; Soilemezi et al., 2017b). This was particularly the case for the carers interviewed by Damme and Ray-Degges, as these two slices of data illustrate:

Oh we can afford it [talking about level access shower], but if it gets bad he won't be able to be here at home ... I don't think we need to make any changes. (Damme and Ray-Degges, 2016: 99)

and

I don't think there is anything that can make her more independent because of her limited ability to move around because she can't stand for a long period of time, and then she has to sit. (Damme and Ray-Degges, 2016: 100)

Limited options, or options that carers would want to use (Lach and Chang, 2007), were often cited as a barrier. Using an example of a raised toilet seat, Pynoos and Ohta (1991) found that some interventions would not work from the start; put simply, what appeared best for the person with dementia may not be best for the carer. Other carers identified modifications as symbols of disability and abnormality:

I try and keep it very basic and very normal, very normal for her. I think that is essential, I don't want her to feel she is an invalid. (Soilemezi et al., 2017b: 320)

Earlier work by Silverstein et al. (1993) had similar findings with a small number of carers not following through on recommendations as they believed the home adaptations would negatively impact on the appearance of the property.

Interestingly, there was also a belief that changing the environment would make no difference, and this was particularly evident in the UK studies. None of the carers in the study by Allen et al. (2019: 8) had looked for information on housing adaptations because 'they did not recognise that it is something that could affect cognitive or behavioural symptoms'. This is illustrated in the work of Soilemezi et al.:

It's his health; the flat doesn't make it worse ... there is no problem in the environment. (Soilemezi et al., 2017b: 320)

\section{The home}

Housing tenure was seen by some carers as preventing an opportunity to make adaptations to the home. In their study, Damme and Ray-Degges noted the concerns of one of their carers:

We rent this place, so we can't change a lot. The floor is not level, but we are used to that by now. We put those cement blocks out front to make the steps easier to get up. (Damme and Ray-Degges, 2016: 99) 
Similarly, Soilemezi et al. had two carers who perceived rental accommodation to be a restriction criterion:

This isn't our flat, so ... I would have it different all together ... I don't want to spend money on somebody else's property ... I may not be here much longer. (Soilemezi et al., 2017b: 320)

Silverstein et al. (1993) also suggested that rental tenures, and the resultant constraints on property adaptation, required further exploration, especially on its impact with caring relationships.

The type of housing was sometimes a barrier to change. Damme and Ray-Degges (2016) provided an example of a carer who was unable to adapt a property because it was a mobile home and therefore it was difficult to replace the entrance steps with a ramp. Size and space were an issue such that not having enough room prevented making changes (Soilemezi et al., 2017b) and egress from a property in the event of a fire was raised by a small number of carers in the study by Olsen et al. (1993), an example being implementing additional door locks.

Finally, the issue of affordability/cost was picked up in a number of studies (Silverstein et al., 1993; Lach and Chang, 2007; Marquardt et al., 2011; Soilemezi et al., 2017b). Whilst there is little detail, major changes were highlighted by Soilemezi et al. with a carer quote being:

After he had had a fall I did think that maybe I ought to think about it [non-slip flooring], but knowing how expensive it is, I haven't done anything at the moment. (Soilemezi et al., 2017b: 321).

Similarly, Marquardt et al. (2011) gave examples of major changes to stairs, bedrooms and bathrooms as being prohibitive.

\section{Scoping review question $3 b$ : What are the enablers to housing adaptation and use?}

Input from an occupational therapist (Allen et al., 2019) or home/community services (Damme and Ray-Degges, 2016) or just 'expert help' (Lach and Chang, 2007) was seen as supporting and enabling implementation and use because it extended the repertoire of solutions beyond those which the carer could identify (Pynoos and Ohta, 1991). In tandem, carers were inventive in having a 'creative and continually evolving perspective' (Olsen et al., 1993: 54) to often develop novel solutions (Soilemezi et al., 2017b). Beyond assistance from professionals and family, Anderson and Rose (2019) found that online support, such as discussion forums, provided opportunity to share with others, ask questions and share levels of success (or otherwise) in using suggested strategies.

The issue of timing was discussed by both Pynoos and Ohta (1991) and Marquardt et al. (2011). They suggested that if an adaptation was implemented in the early stages of dementia then this would be the optimum timing as it would give the person with dementia more time to adjust and assimilate the adaptation into everyday routines. Olsen et al. (1996) referred to this early implementation as the 'assistive' phase in which interventions seek to enhance movement, 
maintain independence and provide increased support within the everyday home environment. Finally, having the 'right size' property in order to have space to implement adaptations (Soilemezi et al., 2017b) and adequate financial resources (Olsen et al., 1993) were briefly mentioned as enabling adaptations to be made to/in the home.

\section{Scoping review question 4: What is the impact of housing adaptations on everyday life?}

The literature suggested that the primary impact of adaptations on the person with dementia was personal safety. Indeed, concern for safety was frequently the impetus for making environmental modifications, with many carers making certain modifications for both safety and independence. Developing this point further, Lach and Chang (2007) found that modifications were often made to the home after an incident or accident had happened, and not beforehand. Calkins and Namazi (1991) suggested that carers viewed safety as a prerequisite for autonomy and being able to move around the home was found to be important for the maintenance of activities of daily living (Allen et al., 2019). Adaptations to prevent falls were often described by carers. For example, Marquardt et al. (2011) found that 57 per cent $(\mathrm{N}=47)$ of people with dementia had fallen at least once in their home within the past two years, with the following areas of the home identified as being most at risk: bedrooms (26\%), living room or den (17\%), bathroom (12\%), house entrance or in the hallway near the home entrance (12\%), and on steps (11\%). The risk of falling on steps and stairs was also highlighted by Damme and Ray-Degges (2016). Examples of lighting, level access showers and grab rails were described in most studies as being installed because of the actual or perceived falls risk, including in the study by Allen et al (2019).

In addition to safety, Calkins and Namazi found that modifications seemed to help, with a quote from one carer in their study indicating that modifications

made the environment less distracting, made the patient more independent, made the patient happier, helped the patient stay home longer, and increased the patients' safety. (Calkins and Namazi, 1991: 28)

In more recent studies, Anderson and Rose (2019) found that modifications impacted positively on the person with dementia because they responded directly to the persons' needs, whilst protecting their dignity and boosting self-confidence.

In terms of practicalities, carers found that modifications helped them to manage the care that they provided (Anderson and Rose, 2019), making it easier and safer to do so (Calkins and Namazi, 1991; Pynoos and Ohta, 1991). Carers also referred to the fact that home adaptations allowed them to compensate for everyday difficulties and made daily life more practical, which helped with increased selfefficacy and wellbeing (Soilemezi et al., 2017b). Such enhanced feelings of 'control' provided better carer outcomes, such as feeling less burdened and having more sleep (Soilemezi et al., 2017b). Using the Zarit Burden Interview (Zarit et al., 1980) to measure stress levels, Silverstein et al. (1993) had previously reported similar findings. In their study, carers with a higher carer burden score were more likely 
to implement modification recommendations, and the authors suggested that 'a cautious implication here is that, just perhaps, the adaptations did have a positive impact on the carers who chose to implement them' (Silverstein et al., 1993: 67).

\section{Discussion}

The aim of this study was to explore the contribution of housing adaptations in supporting everyday life for people with dementia. A scoping review approach was chosen because it allowed for an examination of the evidence, the production of a summary of the findings and the identification of gaps in the literature (Tricco et al., 2018a).

Review question 1 sought to understand which housing adaptations were being implemented and used by people with dementia and their carers on an everyday basis. The scoping review found that the most common adaptations which were recommended and/or implemented were to compensate for a person with dementia's physical limitations, with a significant emphasis placed on personal safety, particularly from falls. Whilst none of the included studies assessed the effects of adaptations on improving safety, there is strong evidence through randomised controlled trials within the more generic literature that home adaptations can improve safety for older adults, particularly those at risk of falling (Keall et al., 2015; Whitehead et al., 2018). Having a more robust evidence base beyond the included studies will be important moving forwards because the wider literature reminds us that safety and predictability of the environment are important for people with dementia (Fæø et al., 2019). However, safety is one of the most prevalent areas of unmet need for people with dementia living in the community (Johnston et al., 2011) and this points a direction towards future attention and action.

The scoping review (review questions 2 and 3 ) found that input and support from professionals, family and online were important because they extended the repertoire of solutions beyond those which the carer could come up with themselves. However, the literature also revealed that carers were often inventive in developing novel solutions (see also Bellass et al., 2019). Some carers in the included studies expressed reservations about the involvement of health and social care professionals, believing that they would not be helpful, the support would not be adequate or they could implement adaptations themselves through trial and error. Within the wider literature, the importance of good quality information and advice on a range of housing matters including adaptations is recognised, e.g. the recent UK House of Commons report on Housing for Older People (House of Commons, 2018) and the Royal College of Occupational Therapists' guidance on planning and delivering housing adaptations differently (Russell et al., 2019). It is important to remember that people living with dementia and carers do not know all the questions to ask, nor how to negotiate health and social care systems for support and advice (Lord et al., 2016). Consequently, carers often find decision making overwhelming, especially if they were new to the role and responsibilities (Lord et al., 2016). In addition, most information and advice is online, yet 33 per cent of 65-74 year olds and 48 per cent of those over 75 do not use the internet (Ofcom, 2019). Professional face-to-face advice on housing adaptations, specifically for the topic area of dementia, would seem crucial and 
in line with the UK government's recent review of the Disabled Facilities Grant in England - which funds housing adaptations (Mackintosh et al., 2018) and which called for better and timelier advice. Furthermore, little is known about the changes people with dementia and carers make to their own homes without professional support (Powell et al., 2017) and there are concerns about improvisation without specialist advice, particularly around issues of personal safety (Steinfeld and Maisel, 2012; Gitlin et al., 2014). Ensuring that people with dementia, carers and professionals are closely involved in person-centred decision making will deliver the best outcomes in terms of housing adaptations (Powell et al., 2017, Russell et al., 2018; Evans et al., 2019).

The scoping review (review question 3) also found that there was a tension between those carers who thought that changes to the home (such as adaptations) should be anticipatory and made early within the lived trajectory of dementia so that changes could be incorporated into the daily routine, as opposed to those carers who thought that changes should only be made when necessary. In keeping with wider research literature, Renault et al. (2015: 1289) refer to this dilemma as 'wait and see (no current modifications) versus action (home modifications or move)'. Similarly, the systematic review by Powell et al. (2017) concluded that there was good evidence that people delay installing adaptations to their home until they reach a point of crisis. In effect, adaptations only become necessary when the fit between the person and their home environment is 'disrupted, compromised or unsafe' (Steinfeld and Maisel, 2012: 246). Going forward, further exploration of this dilemma in a dementia-specific context is necessary.

The scoping review (review question 3) also found that carers were reluctant to make changes if these would cause confusion or irritation in the person with dementia. In the generic literature, Fæø et al. (2019:3) refer to 'the disturbed rhythms in life at home' because often problem behaviours identified at one point in time may not be the most distressing a few weeks later (see also Gitlin et al., 2010). Within the included studies, there was a belief that changing the physical home environment would make no difference (review question 3). This finding is in sharp contrast to the wider literature which establishes a relationship between the environment and wellbeing for people with dementia living at home (Forsund et al., 2018; Gitlin and Hodgson, 2018; Bartlett and Brannelly, 2019). Whilst the likelihood of being disabled and/or experiencing multiple chronic and complex health conditions increases with age (Office for National Statistics, 2018 cited in Age UK, 2019), appropriate housing (including adaptations) can support older people to stay healthy and live independently for longer (Adams and Hodges, 2018). This might reduce the need for social care (House of Commons, 2018) but more research is needed in the area of home adaptations and people with dementia as the underpinning evidence base, especially in a UK context, is largely absent and in need of development.

Within the included studies, the type of housing was often a barrier to implementing adaptations either because it was difficult to adapt a property or there was insufficient room or tenure placed restrictions on what changes could be made. Tenure is particularly problematic, and it is acknowledged within the housing literature that whilst due consideration must be given to potential issues of tenure (Gitlin and Hodgson, 2018), often restrictions imposed on tenants prevent necessary adaptations being implemented (Lipman and Manthorpe, 2010). 
Again, this would appear to be a field of research and policy investigation that is ripe for development in the dementia-specific arena.

The scoping review also sought to understand the impact of housing adaptations on everyday life (review question 4). Within the included studies, carers suggested that housing adaptations helped them to manage the care they provided, making it easier and safer to do so. In an example from the included studies, Soilemezi et al. (2017b) found that carers were able to compensate for difficulties, making daily life more practical, which in turn helped them to feel in control and gave them peace of mind. In effect, they spent less time supervising, and this provided better outcomes such as less burden and more sleep. It has been identified in the wider literature that carer outcomes are an emerging area of evidence within home modification studies (Stark et al., 2017), and this may explain why the remaining included studies provided limited examples of the impact of housing adaptations for the carer. Owing to an emphasis placed on safety within the included studies, there was a lack of evidence as to how housing adaptations impact beyond safety in contributing more generally towards the wellbeing of a person with dementia.

It is known from the public health literature that home adaptations play an important part in the wellbeing and safety of the general population (Heywood and Turner, 2007; Peace and Darton, 2020). It is also known from such literature that home adaptations can improve a range of outcomes for older people in general, including increased levels of confidence and independence (Adams and Hodges, 2018). Within the context of dementia, however, there is little evidence in relation to the value of such (Powell et al., 2017), although Carnemolla and Bridge (2019) have recently reported that for carers, housing adaptations can make a significant contribution to a reduction in the need for care. This paucity of evidence both within the UK and more widely is of concern if housing adaptations are to be fit for purpose for people living with dementia in their own homes.

Finally, across all four review questions there was a predominance of the carer as participant, such that the voices of people with dementia were largely absent from study reporting. At times, from the included literature, it was also difficult to ascertain if the carer was still supporting the person with dementia. More participatory and collaborative research designs would seem to be an important way forward in the housing adaptations field in order to strengthen the voice and participation of people with dementia. This could be underpinned by the use of more creative social research methods, such as video-elicitation methods, that would show as well as tell the stories that were being represented.

\section{Limitations}

Whilst there were some creative research methods in use (e.g. home environment walk-through interviews by Marquardt et al., 2011 and Soilemezi et al., 2017a, 2017b), data collection methods were mainly one-off interviews conducted at home. These snapshots provide little insight into the use, and long-term effects of, the housing adaptation. More immersive data collection methods, such as ethnography, which would allow for the observation of people's behaviour before and after the installation would seem to be important, and this point was also picked up in the wider literature in the systematic review by Powell et al. (2017). 
A scoping review uses an explicit, transparent and peer-reviewed search strategy similar to a systematic review. However, within a scoping review, synthesis of the findings is not undertaken, but the range of located evidence is graphically represented. The existence of studies is used as the basis for conclusions, rather than the intrinsic quality (trustworthiness) of the included studies. This provides a limitation in the absence of quality assessment, in particular, since no studies were excluded on the basis of poor quality.

\section{Conclusion}

The scoping review found that both carers and people with dementia lacked an understanding of their likely dementia trajectory because of the difficulties in accessing readily available information or because they chose not to look to what the future might hold or because of the uncertainty and difficulty in predicting the trajectory due to diversities between individuals. This is similar to findings in the wider literature in the context of dementia and care where it was suggested by Read et al. (2017) that a process of advanced care planning might help carers and people with dementia to identify and address their future support needs more proactively and with appropriate support. From the scoping review findings, it would seem that an assessment of the home with the purpose of advanced housing adaptations planning in the early stages of the trajectory of dementia may help a person with dementia to remain independent for longer.

The findings from the review also revealed that little is known about housing adaptations and dementia within the UK. Only three of the included studies were from the UK (Soilemezi et al., 2017a, 2017b; Allen et al., 2019) and although these studies were timely, they comprise a total of 23 carers and eight people with dementia. Evidence-based policy and practice made within the context of health and social care should be based on the best available evidence and there would seem a dearth of evidence within the UK which could bring a much-needed context to policy planning and implementation. Much remains to be done.

Acknowledgements. Information scientists at the University of Manchester contributed towards the development of the search strategy. Dr Robyn Dowlen (whilst at the University of Manchester) provided advice on the practical implementation of the inclusion criteria. Dr Rachel Russell (whilst at the University of Salford) provided advice on the definition, and interpretation, of housing adaptations/ modifications.

Financial support. This work was supported by the Economic and Social Research Council NWSSDTP (grant number ES/P000665/1).

Conflict of interest. The authors declare no conflicts of interest.

\section{References}

Adams S and Hodges M (2018) Adapting for Ageing: Good Practice and Innovation in Home Adaptations. London: Centre for Ageing Better.

Age UK (2019) Later Life in the UK 2019. London: Age UK.

All-Party Parliamentary Group on Dementia (2019) Hidden No More: Dementia and Disability. London: All-Party Parliamentary Group on Dementia and the Alzheimer's Society. 
Allen F, Cain R and Meyer C (2019) How people with dementia and their carers adapt their homes: a qualitative study. Dementia 18, 1199-1215.

Alzheimer's Australia (2017) BEAT-D App Built Environment Assessment Tool. Western Australia: Dementia Enabling Environments Project (DEEP).

Alzheimer's Society (2015) Making Your Home Dementia Friendly. London: Alzheimer's Society.

Anderson JG and Rose KM (2019) Nonpharmacological strategies used by family caregivers of persons with Alzheimer's disease and related dementias as presented in blogs. Journal of Gerontological Nursing 45, 25-35.

Arksey H and O'Malley L (2005) Scoping studies: towards a methodological framework. International Journal of Social Research Methodology 8, 19-32.

Bartlett R and Brannelly T (2019) Life at Home for People with Dementia. London: Routledge.

Bellass S, Balmer A, May V, Keady J, Buse C, Capstick AJ, Burke L, Bartlett R and Hodgson J (2019) Broadening the debate on creativity and dementia: a critical approach. Dementia 18, 2799-2820.

Booth A (2016) Searching for qualitative research for inclusion in systematic reviews: a structured methodological review. Systematic Reviews 5, 1-23.

Booth A, Noyes J, Flemming K, Gerhardus A, Wahlster P, Van Der Wilt GJ, Mozygemba K, Refolo P, Sacchini D, Tummers M and Rehuess E (2016) Guidance on Choosing Qualitative Evidence Synthesis Methods for Use in Health Technology Assessments for Complex Interventions. Available at http://www. integrate-hta.eu/downloads/.

Bramer WM, Rethlefesen ML, Kleijnen J and Franco OH (2017) Optimal database combinations for literature searches in systematic reviews: a prospective exploratory study. Systematic Reviews 6, 1-12.

Braubach M (2011) Key challenges of housing and health from the WHO perspective. International Journal of Public Health 56, 579-580.

Braun V and Clarke V (2006) Using thematic analysis in psychology. Qualitative Research in Psychology 3, 77-101.

Britten N and Pope C (2012) Medicine taking for asthma: a worked example for meta-ethnography. In Hannes K and Lockwood C (eds), Synthesising Qualitative Research. Chichester, UK: John Wiley \& Sons, pp. 41-57.

Calkins MP and Namazi KH (1991) Caregivers' perceptions of the effectiveness of home modifications for community living adults with dementia. American Journal of Alzheimer's Care and Related Disorders \& Research 6, 25-29.

Care and Repair England with Silverlinks (2017) Making Your Home a Better Place to Live with Dementia. Nottingham, UK: Care \& Repair England.

Carnemolla P and Bridge C (2019) Housing design and community care: how home modifications reduce care needs of older people and people with disability. International Journal of Environmental Research and Public Health 16, 1-12.

Chang S (2018) Scoping reviews and systematic reviews: is it an either/or question? Annals of Internal Medicine 169, 502-503.

Chaudhury H (2008) Remembering Home: Rediscovering the Self in Dementia. Baltimore, MD: Johns Hopkins University Press.

Colquhoun HL, Levac D, O’Brien KK, Straus S, Tricco AC, Perrier L, Kastner M and Moher D (2014) Scoping reviews: time for clarity in definition, methods and reporting. Journal of Clinical Epidemiology 67, 1291-1294.

Damme MJ and Ray-Degges S (2016) A qualitative study on home modifications of rural caregivers for people with dementia. Journal of Housing for the Elderly 30, 88-105.

Deguen S and Zmirou-Navier D (2010) Social inequalities resulting from health risks related to ambient air quality - a European review. European Journal of Public Health 20, 27-35.

Dementia Services Development Centre (2017) Iridis App. Stirling, UK: Dementia Services Development Centre with Space Architects.

Department of Health (2012) Prime Minister's Challenge on Dementia. London: Department of Health.

Department of Health (2015) Prime Minister's Challenge on Dementia 2020. London: Department of Health.

Evans S, Waller S, Bray J and Atkinson T (2019) Making homes more dementia-friendly through the use of aids and adaptations. Healthcare $7,1-11$. 
Fæø SE, Husebo BS, Bruvik FK and Tranvåg O (2019) 'We live as good a life as we can, in the situation we're in' - the significance of the home as perceived by persons with dementia. BMC Geriatrics 19, 158.

Forsund LH, Grov EK, Helvik AS, Juvet LK, Skovdahl K and Eriksen S (2018) The experience of lived space in persons with dementia: a systematic meta-synthesis. BMC Geriatrics 18, 33.

Gitlin L and Hodgson N (2018) Better Living with Dementia. Amsterdam: Elsevier.

Gitlin LN, Winter L, Dennis MP, Hodgson N and Hauck WW (2010) A biobehavioural home-based intervention and the wellbeing of patients with dementia and their caregivers. Journal of the American Medical Association 304, 983-991.

Gitlin LN, Hodgson N, Piersol CV, Hess E and Hauck WW (2014) Correlates of quality of life for individuals with dementia living at home: the role of home environment, caregiver, and patient-related characteristics. American Journal of Geriatric Psychiatry 22, 587-597.

Hammond Care (2015) DesignSmart. Sydney: Hammond Care.

Heywood F (2005) Adaptation: altering the house to restore the home. Housing Studies 20, 531-547.

Heywood F and Turner L (2007) Better Outcomes, Lower Costs. London: Department for Work and Pensions.

House of Commons (2018) Housing for Older People. Second Report of Session 2017-19. London: Communities and Local Government Committee. Available at https://publications.parliament.uk/pa/ cm201719/cmselect/cmcomloc/370/370.pdf.

Housing Our Ageing Population Panel for Innovation (2012) Housing Our Ageing Population: Plan for Implementation. HAPPI2 Report. London: Homes and Construction Agency, Communities and Local Government and Department of Health.

Johnston D, Samus QM, Morrison A, Leoutsakos JS, Hicks K, Handel S, Rye R, Robbins B, Rabins PV, Lyketsos CG and Black BS (2011) Identification of community-residing individuals with dementia and their unmet needs for care. International Journal of Geriatric Psychiatry 26, 292-298.

Keall MD, Pierse N, Howden-Chapman P, Cunningham C, Cummingham M, Guria J and Baker MG (2015) Home modification to reduce injuries from falls in the Home Injury Prevention Intervention (HIPI) study: a cluster randomised controlled trial. Japan Journal of Nursing Science 12, 184-197.

Lach HW and Chang YP (2007) Caregiver perspectives on safety in home dementia care. Western Journal of Nursing Research 29, 993-1014.

Levac D, Colquhoun H and O'Brien KK (2010) Scoping studies: advancing the methodology. Implementation Science 5, 1-9.

Lipman V and Manthorpe J (2010) Gearing Up: Housing, Ethnicity and Dementia. London: Age UK.

Lockwood C, Porrit K, Munn Z, Rittenmeyer L, Salmond S, Bjerrum M, Loveday H, Carrier J and Stannard D (2017) Systematic reviews of qualitative evidence. In Aromataris E and Munn Z (eds), The Joanna Briggs Reviewer's Manual. The Joanna Briggs Institute, chap. 2. Available at https://reviewersmanual.joannabriggs.org/.

Lord K, Livingston G, Robertson S and Cooper C (2016) How people with dementia and their families decide about moving to a care home and support their needs: development of a decision aid, a qualitative study. BMC Geriatrics 16, 68.

Mackintosh S, Smith P, Garrett H, Davidson M, Morgan G and Russell R (2018) Disabled Facilities Grant and Other Adaptations: External Review. London: Ministry of Housing, Communities and Local Government.

Mann WC, Hurren MD, Charvat BA and Tomia MR (1996) Changes over one year in assistive device use and home modifications by home-based older persons with Alzheimer's disease. Topics in Geriatric Rehabilitation 12, 9-16.

Marquardt G, Johnston D, Black BS, Morrison A, Rosenblatt A, Lyketsos CG and Samus QM (2011) A descriptive study of home modifications for people with dementia and barriers to implementation. Journal of Housing for the Elderly 25, 258-273.

Marquardt G, Bueter K and Motzek T (2014) Impact of the design of the built environment on people with dementia: an evidence-based review. Health Environments Research \& Design Journal 8, 127-157.

Moher D, Liberati A, Tetzlaff J, Altman DG and The PRISMA Group (2009) Preferred Reporting Items for Systematic Reviews and Meta-Analyses: the PRISMA Statement. PLOS Medicine 6, e1000097.

Munn Z, Peters MDJ, Stern C, Tufanaru C, McArthur A and Aromataris E (2018) Systematic review or scoping review? Guidance for authors when choosing between a systematic or scoping review approach. BMC Medical Research Methodology 18, 143. 
National Disability Authority (2015) Research for Dementia and Home Design in Ireland. Looking at New Build and Retrofit Homes from a Universal Design Approach: Key Findings and Recommendations Report 2015. Dublin: The Centre for Excellence in Universal Design at the National Disability Authority.

National Institute for Health and Care Excellence (2018) The Assessment, Management and Support of People Living with Dementia and Their Carers (NG97). London: National Institute for Health and Care Excellence.

Ofcom (2019) Online Nation. Available at https://www.ofcom.org.uk/_data/assets/pdf_file/0024/149253/ online-nation-summary.pdf.

Office for National Statistics (2018) Living Longer. Available at https://www.ons.gov.uk/peoplepopulationand\%20 community/birthsdeathsandmarriages/ageing/articles/livinglongerhowourpopulationischangingandwhyit\%20matters/2018-08-03.

Olsen RV, Ehrenkrantz E and Hutchings BL (1993) Creating supportive environments for people with dementia and their caregivers through home modifications. Technology and Disability 2, 47-57.

Olsen RV, Ehrenkrantz E and Hutchings BL (1996) Creating the movement-access continuum in home environments for dementia care. Topics in Geriatric Rehabilitation 12, 1-8.

Papaioannou D, Sutton A, Carroll C, Wong R and Booth A (2010) Literature searching for social science systematic reviews: consideration of a range of search techniques. Health Information and Libraries Journal 27, 114-122.

Peace S and Dalton R (2020) Reflections on cross-cultural comparison of the impact of housing modification/adaptation for supporting older people at home: a discussion. Journal of Aging \& Environment 34, 210-231.

Peters MDJ, Godfrey C, Kahill H, McInerney P, Baldini Soares C and Parker D (2015) Guidance for conducting systematic reviews. International Journal of Evidence-based Healthcare 13, 141-146.

Peters MDJ, Godfrey C, McInerney P, Baldini Soares C, Khalil H and Parker D (2017) Scoping reviews. In Aromataris E and Munn Z (eds), Joanna Briggs Institute Reviewer's Manual. The Joanna Briggs Institute, chap. 11. Available at https://reviewersmanual.joannabriggs.org/.

Powell J, Mackintosh S, Bird E, Ige J, Garrett H and Roys M (2017) The Role of Home Adaptations in Improving Later Life. London: Centre for Ageing Better.

Pynoos J and Ohta RJ (1991) In-home interventions for persons with Alzheimer's disease and their caregivers. Physical and Occupational Therapy in Geriatrics 9, 83-92.

Read ST, Toyne C and Wynaden D (2017) Experiences and expectations of living with dementia: a qualitative study. Collegian 24, 427-432.

Renault S, Ogg J, Petite S and Chamahian A (2015) Home environments and adaptations in the context of ageing. Ageing \& Society 35, 1278-1303.

Russell R, Ormerod M and Newton R (2018) The development of a design and construction process protocol to support the home modification process delivered by occupational therapists. Journal of Aging Research 2018, 4904379.

Russell R, Walker M, Coperman I and Porteus J (2019) Adaptations Without Delay: A Guide to Planning and Delivering Home Adaptations Differently. London: Royal College of Occupational Therapists.

Silverstein N, Hyde J and Ohta R (1993) Home adaptations for Alzheimer's households: factors related to implementation and outcomes of recommendations. Technology and Disability 2, 58-68.

Soilemezi D, Drahota A, Crossland J, Stores R and Costall A (2017a) Exploring the meaning of home for family caregivers of people with dementia. Journal of Environmental Psychology 51, 70-81.

Soilemezi D, Kallitis P, Drahota A, Crossland J, Stores R and Costall A (2017b) The impact of the physical home environment for family carers of people with dementia: a qualitative study. Journal of Housing for the Elderly 32, 303-333.

Stark S, Keglovits M, Arbesman M and Lieberman D (2017) Effect of home modification interventions on participation of community dwelling adults with health conditions: a systematic review. American Journal of Occupational Therapy 71, 1-11.

Steinfeld E and Maisel JL (2012) Universal Design: Designing Inclusive Environments. Hoboken, NJ: John Wiley \& Sons.

Struckmeyer R and Pickens $\mathbf{N}$ (2016) Home modifications for people with Alzheimer's disease: a scoping review. American Journal of Occupational Therapy 70, 1-9.

Torrington J (2014) What Developments in the Built Environment Will Support the Adaptation and 'Future Proofing' of Homes and Local Neighbourhoods so that People Can Age Well in Place Over the Life Course, 
Stay Safe and Maintain Independent Lives? (Future of an Ageing Population: Evidence Review). London: Foresight, Government Office for Science.

Tricco AC, Antony J, Soobiah C, Kastner M, MacDonald H, Cogo E, Lillie E, Tran J and Straus SE (2016) Knowledge synthesis methods for integrating qualitative and quantitative data: a scoping review reveals poor operationalization of the methodological steps. Journal of Clinical Epidemiology 73, 29-35.

Tricco A, Zarin W, Ghassemi M, Nincic V, Lillie E, Page MJ, Shamseer L, Anthony J, Rios P, Hwee J, Angeliki-Veroniki P, Moher D, Hartling L, Pham B and Straus SE (2018b) Same family, different species: methodological conduct and quality varies according to purpose for five types of knowledge synthesis. Journal of Clinical Epidemiology 96, 133-142.

Tricco AC, Lillie E, Zarin W, O'Brien KK, Colquhoun H, Levac D, Moher D, Peters MDJ, Horsley T, Weeks L, Hempel S, Akl EA, Chang C, McGowan J, Stewart L, Hartling L, Aldcroft A, Wilson MG, Garrity C, Lewin S, Godfrey CM, Macdonald MT, Langlois EV, Soares-Weiser K, Moriarty J, Clifford T, Tuncalp O, Straus SE (2018a) PRISMA extension for Scoping Reviews (PRISMA-ScR): checklist and explanation. Annals of Internal Medicine 169, 467-473.

Whitehead P, Golding-Day M, Belshaw S, Dawson T, James M and Walker M (2018) Bathing adaptations in the homes of older adults (BATH-OUT): results of a feasibility randomised controlled trial (RCT). BMC Public Health 18, 1293.

Wittenberg R, Hu B, Barra-Araiza L and Rehill A (2019) Projects of older people with dementia and costs of dementia care in the United Kingdom, 2019-2040. Care Policy and Evaluation Centre, London School of Economics and Political Science, London, CPEC Working Paper 5.

World Health Organization (2011) Environmental Burden of Disease Associated with Inadequate Housing. Summary Report. Copenhagen: World Health Organization Regional Office for Europe. Available at http://www.euro.who.int/en/publications/abstracts/environmental-burden-of-disease-associated-withinadequate-housing.-summary-report.

Zarit SH, Reever KE and Bach-Peterson J (1980) Relatives of the impaired elderly: correlates of feelings of burden. The Gerontologist 20, 649-655.

Cite this article: Newton R, Adams S, Keady J, Tsekleves E (2021). Exploring the contribution of housing adaptations in supporting everyday life for people with dementia: a scoping review. Ageing \& Society 1-27. https://doi.org/10.1017/S0144686X21001367 